\title{
Artvin Kamu Hastanelerinde Çalışan Yöneticilerin İleri Maliyet Yönetimi Yaklaşımları Konusundaki Algılarının Belirlenmesi ${ }^{1}$
}

$* * *$

\section{Determining The Perceptions of Administrators Working in Artvin Public Hospitals on Advanced Cost Management Approaches}

\author{
Dr. Öğr. Üyesi Muhammed Ardıç \\ Artvin Çoruh Üniversitesi, İşletme Fakültesi, ardic@artvin.edu.tr \\ ORCID: 0000-0002-2439-7247 \\ Dr. Öğr. Üyesi Osman Yıılızlar \\ Avrasya Üniversitesi, Sağlık Bilimler Fakültesi, oyldzlar@hotmail.com \\ ORCID: 0000-0002-5485-8702 \\ Emel Karakullukçu \\ Hemşire, Borçka Devlet Hastanesi,emelkarakullukcu_@hotmail.com \\ ORCID: 0000-0002-0843-1716
}

\begin{abstract}
Özet
Bu çalışmanın temel amacı Artvin Kamu Hastanelerinde görev yapan mali yönetimle ilgili yöneticilerin maliyetlere bakış açıları, ileri maliyet yönetimi yaklaşımları konusunda bilgi düzeyleri ve bu yaklaşımlarının hastanelerde uygulanabilmesi üzerine algılarının belirlenmesidir. Çarıkçı (2014) tarafından geliştirilen ölçek kullanılarak, söz konusu hastanenin mali işlerinden sorumlu toplam 14 yöneticiye kesitsel bir araştırma modeli uygulanmış ve veriler yüz yüze görüşme ile toplanmıştır. Verilerin tanımlayıcı istatistiksel sonuçları SPSS 16.0 istatistik yazılımı kullanılarak elde edilmiştir. Çalışmanın sonuçları, katılımcıların tamamına yakınının ileri maliyet yönetimi yaklaşımlarını daha önceden duyduklarını, bu konuda ileri düzeyde bilgiye sahip olduklarını ve ileri maliyet yönetimi yaklaşımlarının hastanelerinde uygulanabileceğini düşündüklerini göstermiştir. Ayrıca katılımcıların hastanelerde etkin maliyet ve performans sisteminin kurulmamasının hastane karlılığını ve maliyetleri olumsuz yönde etkilediği görüşünde oldukları ortaya çıkmıştır. Ancak, idari ve ilgili mevzuatlarda düzenlemeler yaparak, gelişmiş maliyet yönetimi yaklaşımları ile bu sorunların giderilebileceği belirlenmiştir.
\end{abstract}

Anahtar Kelimeler: Hastane Yöneticileri, Maliyet Yönetimi, Maliyet Yönetimi yaklaşımları JEL Sinıflandırması: M15, M41, M49

\begin{abstract}
The main purpose of this study is to determine the perceptions of the finance managers working for Artvin Public Hospitals about their perspectives on costs, their knowledge about advanced cost management approaches and their application in hospitals. Using the scale developed by Çarıkçı (2014), a cross-sectional research model was conducted to a total of 14 managers responsible for the financial affairs of the hospital in question, and data was collected by face-to-face interview. Descriptive statistical results of the data was obtained using SPSS 16.0 statistical software. The results of the study showed that almost all of the participants heard about advanced cost management approaches before, had advanced knowledge on this issue and thought that advanced cost management approaches could be applied in their hospitals. In addition, it was revealed that the participants were of the opinion that the failure to establish an effective cost and performance system in hospitals negatively affect hospital profitability and costs.
\end{abstract}

\footnotetext{
${ }^{1}$ Bu makale Emel Karakullukçu tarafından Avrasya Üniversitesi, Sağlık Bilimleri Enstitüsü, Sağl. Kur. İşl. ve Yön. Anabilim Dalında Dr. Öğr. Üyesi Muhammed Ardıç ve Dr. Öğr. Üyesi Osman Yıldızlar danışmanlığında tamamlanan “Artvin Kamu Hastanelerinde Çalışan Yöneticilerin İleri Maliyet Yönetimi Yaklaşımları Konusundaki Algılarının Belirlenmesi” adlı yüksek lisans tezinin bir bölümünden yararlanarak hazırlanmıştır.
} 
However, it was determined that it can be troubleshooting these problems with advanced cost management approaches, by making arrangements in administrative and related legislations.

Keywords: Hospital Managers, Cost Management, Cost Management Approaches

JEL Classification: M15, M41, M49

\section{GİRIȘ}

Sektörde ayakta kalabilmek, baş döndürücü şekilde gelişen iletişim ve ileri teknolojinin kullanılması, inovasyon ve sürekli değişen rekabet koşullarında sektörde üretim yapan ya da hizmet üreten günümüz işletmelerinin çevresi, sektörü ve iç dinamiklerini senkronize ederek kaynaklarını etkin ve verimli kullanmasını sağlayacak proaktif bir yaklaşımın benimsemesini önemli kılmaktadır. Politika belirleyicileri kamu işletmelerinin finansmanı ile ilgili politikalar geliştirerek, maliyeti düşürürken kaliteyi azaltacak düzenlemelerden kaçınmalıdırlar. Bu bağlamda maliyet yönetimi ile ilgili reel düzenlemeleri içeren politikalar üretilmesi önem arz etmektedir.

Sağl1k sektörünün içinde bulunduğu zorlu rekabet ortamında işletmelerin karşılaştıkları ana sorunların başında kaliteli hizmet ya da mal üretememek, etkin maliyet belirleyememek ve mali yönetim eksikliği gelmektedir (Örnek, 2003:213). Yaşanılan bu sıkıntılar işletmelerin hizmet ya da mal üretiminde katlandıkları maliyetleri düzenlemelerinde ciddi sorunlara yol açabilir. Sayılan bu unsurları minimize edilebilmesi için özellikle maliyet odaklı yönetim anlayışının benimsenmesi fayda sağlayabilir.

1980'li yıllarda başlayıp günümüzde de gittikçe yaygınlaşan ve tercih edilen ileri maliyet yönetimi yaklaşımları işletmelerin mali açıdan etkin yönetilmeleri bağlamında önem arz etmektedir.

Odağında insan ve onun sağlığı olan sağlık hizmetlerinin hakkaniyetli, adil, erişilebilir, güvenli ve etkin sunumu, toplumsal refahın bir göstergesidir. Bu önemli hizmetin verilmesinde personel ve teknik donanımın nitelik ve nicelik yönden yeterli olması gerekmektedir. Sağlık hizmetleri sağlayıcıları olan kamu ve özel sağlık işletmelerinin gerekli donanım ve altyapıya yatırımı yapmaları kaçınılmaz olarak görülmektedir (Altay, 2007: 40).

Sağl1k sektörü tüm dünyada olduğu gibi ülkemizde de diğer sektörlere göre hızla büyümektedir. Son 15 yılda ülkemiz ekonomisindeki olumlu gelişmeler ve sağlık politikalarında yapılan yönetsel ve uygulamaya yönelik köklü reformlar sağlık hizmetlerinde hizmete erişebilirliği arttırmış, sağlı hizmetinin daha etkin ve kaliteli halde alınmasını sağlamıştır. Sağlık hizmetleri arz ve talebinin etkileşim içerisinde olduğu sağlık hizmetleri piyasasında sunulan hizmetlerin çeşitliliği, yüksek tıbbi teknolojiye ihtiyacın olması, emek yoğun işletmeler olması, personel sayısının artması ve profesyonelleşme oranının yüksek olması gibi unsurlar sağlık hizmetlerine olan talebin artmasına neden olmuştur (Saraçoğlu ve Öztürk 2017: 302).

Hastaneler; sağlık hizmetlerinde iş yükü anlamında sağlık hizmetinin büyük kısmını karşılayan, emek yoğun ve en karmaşık işletmeler olarak görülmektedir. Toplumların refah seviyesini işaret eden en önemli parametrelerden biride verilen sağlık hizmetinin nitelik ve nicelik açısından üst düzeyde olmasıdır. Teknolojik gelişmeler sağlık hizmeti alıcılarının beklenti düzeyini de yükseltmiştir. Bu durum hizmetin sürekliği ve kaliteyi devam ettirebilmeleri için hastaneleri yeni mali yüklerin altına girmek zorunda bırakmıştır. Sosyal devlet anlayışına sahip olan kamu hastanelerinde temel amaç kar alde etmek olmasa da; verilen hizmetin etkinliği, zamanında sunulması, erişebilirliği ve beklentileri karşılaması gibi birçok maliyete de katlanmaları gerekmektedir.

Toplumların refah düzeyleri yükseldikçe, sağlığa verilen önem de artmakta, kişiler daha fazla harcama yapmakta, ülkeler sağlık giderleri için bütçelerinden daha fazla kaynak ayırmaktadırlar. (Tatarlı, 2007: 6). 
Hastanelerde sağl1klı ve doğru maliyetin doğru tespit edilmesi, israfi önleyerek maliyetlerin düşürülmesine, etkin gider planlamasını ve karar verme sürecinde yöneticilere yardımcı olmasını sağlayacağı için büyük önem arz etmektedir. Bu durum hastanelerde mali açıdan bir yönetimin gerekliliğini göstermektedir.

Bu çalışma; hastanelerde görev yapan mali ve finans yönetimi ile ilgili yöneticilerin ileri maliyet yönetimi yaklaşımları konusunda bilgi ve algıları düzeylerini belirlemek amacıyla yapılmıştır. Bu konuda Türkiye'de yapılmış olan çalışmalara bakıldığında bu çalışmaların sınırlı sayıda olduğu görülmüştür. Bu da çalışmanın önemini artırmaktadır.

\subsection{Literatür Araştırması}

Maliyet yönetimi yaklaşımlarının farklı sektörlerdeki uygulabilirliklerine yönelik çok sayıda çalışma olmakla birlikte hastane işletmelerinde uygulanabilirliği konusunda yapılan çalışmaların ise sınırlı sayıda olduğu görülmüştür. Sağlık sektörünü konu alan maliyet yönetimi yaklaşımları ile ilgili yapılmış literatür çalışmaları şöyledir;

Bekçi ve Özal tarafından 2010 yılında, stratejik maliyet yönetiminin sağlı işletmelerine uygulanabilirliğine özel hastanelere yönelik yaptıkları çalışmada; tam zamanında üretim ortamında maliyetlemenin ve kalite maliyetlemenin uygulanabilir olduğunu ortaya koymuşlardır (Bekçi ve Özal, 2010).

Çarıkçı ve Acar tarafindan 2017 yılında, Türkiye'de faaliyet gösteren kamu hastanelerinin yöneticilerinin, çağdaş maliyet yönetimi yaklaşımlarına ve hastane maliyetlerini etkileyen faktörlere ilişkin görüşlerini tespit etmeye yönelik çalışma yapmışlardır. Yapılan bu çalışmada; hastane yöneticilerinin genel olarak çağdaş maliyet yönetimi yaklaşımlarından haberdar oldukları, yaklaşımları bildikleri ve bu yaklaşımlardan hedef maliyetleme hariç diğer yaklaşımların hastanelerde uygulanabilir/ kısmen uygulanabilir olduğu ortaya konulmuştur (Çarıkçı ve Acar, 2017).

Koçyiğit vd. tarafından 2019 yılında, Ankara ilinde faaliyette bulunan özel hastane yöneticilerinin, özel hastanelerin çoğunda stratejik maliyet yönetiminin uygulandığını düşündükleri, ayrıca hastanelerde stratejik maliyet yönetimini uygulanabilir bulduklarını ifade etmişlerdir (Koçyiğit vd. 2019).

Literatürde kredi hacmi ile ekonomik büyüme arasındaki ilişkiye yönelik çalışmalar daha çok finansal gelişme ve ekonomik büyüme kapsamında ele alınmaktadır. Finansal gelişmenin ekonomik büyümeyi mi yoksa ekonomik büyümenin finansal gelişmeyi mi sağladığı sorusunun cevabının tespiti için yapılan çalışmalarda farklı sonuçlara ulaşılmıştır.

\subsection{Maliyet ve Maliyet Yönetimi Kavramları}

Maliyet, bir malın temin edilmesi ya da bir hizmetin yerine getirilmesi için, doğrudan veya dolaylı olarak katlanılması gereken ölçülebilir fedakârlıkların toplamıdır (Gürsoy, 1997). Başka bir ifadeyle maliyet; herhangi bir malı veya hizmeti, kullanıldığ 1 ve satıldığı yerdeveya durumda elde edebilmek için doğrudan ya da dolaylı olarak yapılan toplam harcamalardır (Akdoğan, 1998).

Bu tanımlar bize sahip olunmak istenen her mal ya da hizmet için ayrı ayrı maliyetin olması gerektiğini belirtmektedir (Büyükmirza, 2012). Bu tanımlara göre bir maliyetten söz edebilmek için mal ya da hizmete sahip olunmasına yönelik faaliyetin gösterilmesi ve parasal olarak da bir değerin belirlenmesi gerekliliği ortaya çıkmaktadır.

Sağlık hizmetlerinde maliyet kavramı da benzer şekilde tanımlanabilmektedir. Maliyetler direkt maliyetler, endirekt maliyetler ve maddi olmayan maliyetler olarak genellikle üç grupta toplanmaktadır. Bir girişimin yapılabilmesi için ve girişime bağlı bugün ve gelecekte oluşabilecek yan etkileri tedavi etmek için kullanılacak kaynakların tümü direkt tıbbi maliyetleri oluşturmaktadır. Direkt maliyetler tıbbi bakımla ilgili maliyetleri ve tıbbi bakımla ilgili olmayan maliyetleri içermektedir (Robertson and Hill 2003: 74). Tibbi 
bakımla ilgili maliyetlere örnek olarak ilaç, tıbbi konsültasyon, tetkik, yan etki tedavisi, yan etkilerle ilgili hastaneye yatış, poliklinik başvuruları, hekim giderleri, sağlık personeli tarafından evde sunulan bakım verilebilmektedir. Tıbbi bakımla ilgili olmayan maliyetler ise yiyecek ve içecek, ulaşım ve konaklama giderlerini içermektedir (Özgen, Tatar 2007: 111).

Endirekt maliyetler; sağlık hizmetlerinde tıbbi hizmetlerle direkt ilgili olmayan ve hastanın veya refakatçisinin işgücü kaybı nedeniyle meydana gelen maliyetlerdir. Bu gibi maliyetlerde çoğunlukla piyasa fiyatları oluşmadığı için maliyetlerinin tespit edilmesini zorlaştırmaktadır. Maddi olmayan maliyetlere; hasta ve yakınlarının hizmete erişiminde ödedikleri nakit ödemeler ve diğer kamusal harcamalar girmektedir. Bu maliyet türünün tespiti de oldukça güçtür (Özgen ve Tatar, 2007: 112).

Maliyet yönetimi kavramı maliyet muhasebesine göre daha geniş kapsamlı bir kavramdır. Maliyet yönetimi, bir işletmede ürün ve işlemleri geliştirmek amaciyla organizasyon yapmak, ölçmek, değerlendirerek analiz edip geri bildirim yapmak için seçilen yöntem ya da teknik olarak ifade edilebilir (Karcioğlu, 2000:65). Maliyet yönetimi genel anlamda ürün ve hizmet maliyetlerini doğru bir şekilde belirlemek, işlemleri geliştirmek, israfın önüne geçmek, ilgili faaliyetleri planlama ve tanımlama süreçlerini içine alan bir yönetim tekniğidir (Yüzbaşığlu, 2004; Özkan vd., 2013).

Yapılan tanımlara bakıldığında maliyet yönetimi günümüz klasik muhasebe işlemlerinden oldukça farklılaşarak işlevsel bir yapı olarak karşımıza çıkmaktadır. Maliyet yönetimi, ham madde tedarikinden üretime, ARGE çalışmalarından depolama vb. bir işletmede olması gereken ana süreçlerin etkin bir organizasyon yapısı ile yönetimi şeklinde değerlendirilmektedir (Ardıç, 2010: 14).

\subsection{Sağglık Hizmetlerinde Maliyet Yönetimi ve Özellikleri}

Rekabet tüm sektörlerde olduğu gibi sağlık sektöründe de önemini hissettirmektedir (Özkan vd., 2013). Bu sektörden hizmet alanların hizmet kalitesi ve etkinliği açısından sürekli ve hızlı bir değişim içinde olması, sağlık hizmetlerinin bilişim ve teknolojik gelişmelere kısa sürede ayak uydurması, yeniliklere açık bir sektör olması ve organizasyonun yönetimi yönünden kendine has özellikleri olması diğer sektörlerden kendini açık ara ön plana çıkarmaktadır. Bu özelliklere sahip olan sağlık hizmetleri ve bu alanda hizmet veren hastanelerin sektörde devamlığını sürdürebilmesi oldukça güç görünmektedir. Kaliteli ve güvenli sağlık hizmeti vermek için kurumsal finansal sürdürebilirliğin sağlanması gerekmektedir (Özer, 2015:41).

Hastanelerin sektörde ayakta durabilmesi için etkili bir maliyet yönetimi sergilemesi ve bu yaklaşımında hastane yönetimi tarafından önemsenmesi ve dikkate alınması gerekmektedir (Özgener ve Küçük,2008: 346; İncesu, 2013).

Sağlık hizmetlerinin yürütülmesinde lokomotif görevi gören hastanelerin kendine özgü bir dizi özellikleri bulunmaktadır. Sağlı hizmetleri teknoloji ve emek yoğun işletmeler olmasının yanı sıra, verilen hizmetin insan faktörüne dayanması nedeniyle arzı pahalı bir özelliği vardır. Sağlık hizmetlerinde teknolojinin kullanımı hem çeşitlilik hem de oransal olarak oldukça fazladır. Ayrıca kullanılan teknoloji oldukçada pahalıdır. Kullanılan teknolojinin takip edilmesi sektörde sürekliliği sağlama açısından ve rekabet unsuru olası açısından önemlidir (Özgülbaş ve Tarcan, 2013: 42).

Ayrıca hastane işletmelerinin diğer birçok hizmet işletmesine göre daha geniş ürün/hizmet yelpazesine ve daha karmaşık bir faaliyet yapısına sahip olması dolayısıyla maliyetlerin belirlenmesindeki zorluklar nedeniyle hastane işletmelerinde ileri maliyet yönetimi yaklaşımlarının uygulanabilirliği konusu güncelliğini korumaktadır (Koçyiğit vd., 2019: 67).

Hastaneler sadece tedavi hizmetleri vermemekte, bunun yanında koruyucu sağlık hizmetlerini, araştırma ve geliştirme çalışmalarının yapmalarından dolayı hizmet alanında kendi için de de farklılaşmaktadırlar. Örneğin eğitim ve araştırma hastaneleri, üniversite hastaneleri, dal hastaneleri, vakıf hastaneleri, özel hastaneler gibi sıralanabilir. Bu sınıflandırılma hastanelerin farklı mali profillerini de ortaya çıkarmaktadır. 
Görüleceği üzere sağlık hizmetlerinde verilen hizmet çeşitliği ve kullanılan malzeme ve iş gücünün fazlalığ1 maliyetlerin doğru hesaplanmasını ve minimize edilmesini zorlaştırmaktadır.

Yukarıda sayılan farklı grup sağlık işletmeleri kaçınılmaz olarak farklı sayıda ve özellikte iş gücüne gerek duymaktadırlar. Sağlık hizmetlerinin her aşmasında sağlık profesyonellerine ihtiyaç duyulmaktadır. Bu sektörde uzmanlaşma oldukça yüksektir. Bu durum verilen hizmetin doğal olarak maliyetini de artmasına neden olmaktadir.

\section{YÖNTEM}

\section{1. Çalışmanın Modeli}

Artvin Kamu Hastanelerine bağlı hastanelerde görev yapan yöneticilerin ileri maliyet yönetimi yaklaşımları konusunda bilgi ve düşüncelerini tespit etmeği amaçlayan bu çalışma kesitsel araştırma modeli temel alınarak gerçekleştirilmiştir.

\section{2. Çalışmanın Önemi}

Hastanelerde sunulan hizmetlerin etkili ve etkin bir şekilde verilebilmesi ve aktarılan maddi kaynakların verimli bir şekilde kullanılması için, belirlenecek olan bir ya da daha fazla maliyet yönetimi yaklaşımının başarıyla uygulanması tatbik edilmesi önem arz etmektedir. Bu çalışmada, mali kaynakları başarılı bir şekilde yönetmeleri beklenen hastane yöneticilerinin, maliyet yönetimi ile ilgili bilgi, beceri ve tecrübe düzeylerinin değerlendirilmesi amaçlanmıştır.

\section{3. Çalışmanın Kısıtlııkları}

Bu çalışmaya Artvin Kamu Hastanelerine bağlı hastanelerde maliyet yönetimi açısından bilgili ve yetkiye sahip yöneticiler dahil edilmiş, bu yöneticilerin dışında kalanlar çalışma dışında tutulmuştur. Çalışmanın çıktıları sadece araştırmaya dâhil edilen hastane yöneticileri için genelleme yapılabilir.

\section{3.Çalışmanın Evreni ve Örneklemi}

Araştırmanın evrenini 2016 y1lı itibariyle faaliyet gösteren Artvin Kamu Hastanelerine bağlı 6 hastane oluşturmaktadır. Tamsayım yönetimi dâhilinde örneklem seçimine gidilmeyerek evreni oluşturan 6 hastanenin mali yönetim ile ilgili toplam 14 yöneticisinin tamamına ulaşılmıştır. Çalışmanın yapıldığı yıl (2016) itibariyle etik kurul izin belgesi gerekmediğinden sadece kurum yöneticisi ile görüşüp sözlü izin alınmıştır.

\subsection{Veri Toplama Araçları ve Uygulama}

Çalışmanın verileri, Çarıkçı tarafından oluşturulan soru seti kullanılarak elde edilmiştir (Çarıkçı, 2014). Çalı̧̧mada kullanılan soru setleri üç bölümden oluşmaktadır. Soru setinin ilk bölümünde, katılımcılara ait demografik özelliklerini belirlemeye yönelik sorular, ikinci bölümde ise beşli likert ölçeğine göre hazırlanmış katılımcıların hastanelerde karlılığı etkileyen faktörler konusundaki tutumlarımı belirlemeye yönelik sorulardan oluşmaktadır. Üçüncü ve son bölümde ise daha önceden belirlenmiş ve literatürde geçen 12 ileri maliyet yönetim yaklaşımının hastane yöneticileri açısından algı ve uygulama düzeylerinin belirlenmesine yönelik sorular sorulmuştur. Soru setleri katılımcılara yüz yüze anket uygulama yönetimi ile uygulanmıştır. Verilerin içerik geçerliliğini sağlamak amacıyla bu konuda çalışma yapmış olan 4 muhasebe akademisyeninden anketin uygulanabilir olduğu hususunda olumlu görüş alınmıştır. 


\subsection{Araştırma Soruları}

Çalışma kapsamında elde edilen veriler ve örneklem sayısı t testi yapmaya yeterli olmadığı için yüzyüze görüşmelerden elde edilen veriler ve tanımlayıcı istatiksel verilerden alınan cevaplarla karşılaştırmak üzere araştırma soruları şu şekilde belirlenmiştir;

1-Katılımc1lar ileri maliyetleme yaklaşımları konusunda haberdar olma düzeyleri hangi seviyededir?

2-Katılımcılar ileri maliyetleme yaklaşımları hakkında hangi düzeyde bilgi sahibidirler?

3-Katılımcılar ileri maliyetleme yaklaşımlarının hastanelerinde hangi düzeyde uygulanabilir olduğunu düşünmektedirler?

4-Katılımcılar hastanelerinde karlılığı ve maliyetleri etkileyen faktörler konusunda düşünceleri nelerdir?

\subsection{Verilerin Analizi ve Değerlendirilmesi}

Veriler SPSS 16.0 paket programında tanımlayıcı istatistik (frekans, aritmetik ortalama, standart sapma ve yüzdelik) analiz yapılarak elde edilmiştir.

\section{BULGULAR}

Çalışmada elde edilen veriler, tablolar oluşturularak değerlendirilmiştir. Çalışmaya katılanların eğitim durumlarına göre dağılımlarına bakıldığında yükseköğrenimli katılımcı sayısı (yüksek lisans ve doktora) \%57 olduğu, geriye kalan \%43 ise lisans mezunu düzeyinde olduğu belirlenmiştir (Tablo 1).

Tablo 1. Çalışanların Demografik Özelliklere Göre Dağılım Durumu

\begin{tabular}{|c|c|c|}
\hline Özellikler & Sayı(n) & Yüzde(\%) \\
\hline \multicolumn{3}{|l|}{ Eğitim Durumu } \\
\hline Lisans & 6 & 42,9 \\
\hline Yüksek Lisans & 3 & 21,4 \\
\hline Doktora & 5 & 35,7 \\
\hline \multicolumn{3}{|l|}{ Pozisyon-Görev Durumu } \\
\hline Hastane Yöneticisi & 6 & 42,9 \\
\hline İdari Mali İssler Müdürü & 6 & 42,9 \\
\hline İdari Mali İşler Müd. Yrd. & 2 & 14,3 \\
\hline \multicolumn{3}{|l|}{ Toplam Kıdem Yılı } \\
\hline $5-10$ & 7 & 50 \\
\hline $10-20$ & 3 & 21,4 \\
\hline 20> & 4 & 28,6 \\
\hline \multicolumn{3}{|c|}{ Son Görevde Mevcut Kıdem Yılı } \\
\hline$<1$ & 6 & 42,9 \\
\hline $1-3$ & 5 & 35,7 \\
\hline $3-7$ & 2 & 14,3 \\
\hline $10>$ & 1 & 7,1 \\
\hline \multicolumn{3}{|c|}{ Mezun Olunan Bölüm/Program } \\
\hline Tip & 6 & 42,9 \\
\hline İşletme & 6 & 42,9 \\
\hline İktisat & 1 & 7,1 \\
\hline Kamu Yönetimi & 1 & 7,1 \\
\hline \multicolumn{3}{|l|}{ Hastane yatak kapasitesi } \\
\hline $25-50$ & 8 & 57,1 \\
\hline $50-100$ & 3 & 21,4 \\
\hline $100>$ & 3 & 21,4 \\
\hline
\end{tabular}

Katılımcıların sıklıkla \%42,9'u hastane yöneticisi ve idari mali işler müdürü, \%14,3'ü ise idari mali işler müdür yardımcısı pozisyonunda faaliyet gösterdiği, katılımcıların yarısı 5-10 yıl arası kıdem yıllık hizmet süresine sahip olduğu, diğer yarısının ise 10 yıl ve üzeri hizmeti olanlarının oluşturduğu, 6'si $(\% 42,9)$ bir yıldan az, 5'i(\%35,7) ise 1-3 yıl arası hastanede yönetici olarak görev yaptı̆̆ 1 , hastanede yönetici 
pozisyonunda çalışan 11(\%78,6) çalışanın mevcut görevlerine yeni başladıklarını göstermektedir. Katılımcıların mezun oldukları bölüm/programa göre dağılımlarını bakıldığında, tıp ve işletme bölüm mezunu katılımcıların oranı her ikisinde de en sıklıkla \%42,9 olduğu, bu durum çalışmaya katılan katılımcıların ağırlıklı olarak tıp mezunu hastane yöneticileri ile işletme mezunu hastane idari mali işler müdürlerinin olduğunu göstermektedir. Diğer bölümler (iktisat ve kamu yönetimi) ise \%7,1 ile sıralanmıştır. Çalışmanın yapıldığı hastanelerin yarısından fazlası $(\% 57,1)$ 25-50 yatak sayısı aralığına sahip küçük ölçekli hastanelerin olduğu görülmektedir. Diğer hastanelerin 3'ü 50-100, yine 3 hastanede bir diğeri grup olan 100 yatak ve üzeri olan hastane olarak belirlenmiştir (Tablo 1).

Tablo 2. Katılımcıların İleri Maliyet Yaklaşımları Hakkında Bilgi Edinme Yerlerine Göre Dağılımı

\begin{tabular}{|c|c|c|c|c|c|c|c|c|c|c|c|c|}
\hline & & 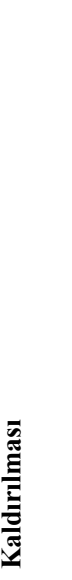 & & 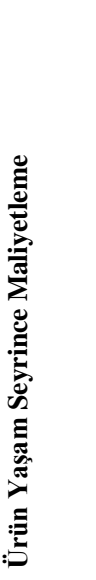 & & 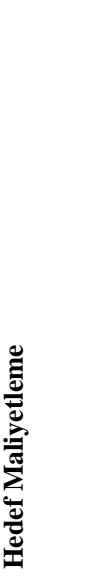 & & 胥 & & 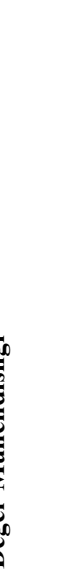 & & 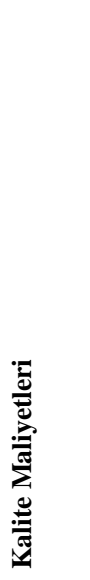 \\
\hline 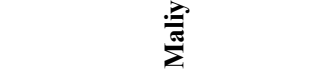 & $\mathbf{n}$ & $\%$ & $\mathbf{n}$ & $\%$ & $\mathbf{n}$ & $\%$ & $\mathbf{n}$ & $\%$ & $\mathbf{n}$ & $\%$ & $\mathbf{n}$ & $\%$ \\
\hline $\begin{array}{l}\text { Aldığım kurs, hizmet içi } \\
\text { eğitim, seminer vs. }\end{array}$ & 7 & 23,3 & 5 & 20,8 & 8 & 29,6 & 9 & 37,5 & 8 & 27,6 & 12 & 22,2 \\
\hline $\begin{array}{l}\text { Almış olduğum üniversite } \\
\text { eğitimi vs. }\end{array}$ & 8 & 26,7 & 7 & 29,2 & 7 & 25,9 & 5 & 20,8 & 9 & 31,0 & 8 & 14,8 \\
\hline Meslektaşlarımdan & 2 & 6,7 & 1 & 4,2 & 5 & 18,5 & 2 & 8,3 & 3 & 10,3 & 8 & 14,8 \\
\hline $\begin{array}{l}\text { Yazil, görsel } \\
\text { dokümanlardan veya } \\
\text { internet }\end{array}$ & 7 & 23,3 & 6 & 25,0 & 4 & 14,8 & 6 & 25,0 & 7 & 24,1 & 11 & 20,4 \\
\hline $\begin{array}{l}\text { Hastanedeki uygulamalar } \\
\text { sirasında }\end{array}$ & 5 & 16,7 & 4 & 16,7 & 3 & 11,1 & 2 & 8,3 & 1 & 3,4 & 11 & 20,4 \\
\hline Diğer & 1 & 3,3 & 1 & 4,2 & & 0,0 & & 0,0 & 1 & 3,4 & 4 & 7,4 \\
\hline Toplam & 30 & 100 & 24 & 100 & 27 & 100 & 24 & 100 & 29 & 100 & 54 & 100 \\
\hline
\end{tabular}


Tablo 2. Katılımcıların İleri Maliyet Yaklaşımları Hakkında Bilgi Edinme Yerlerine Göre Dağılımı (Devam)

\begin{tabular}{|c|c|c|c|c|c|c|c|c|c|c|c|c|}
\hline 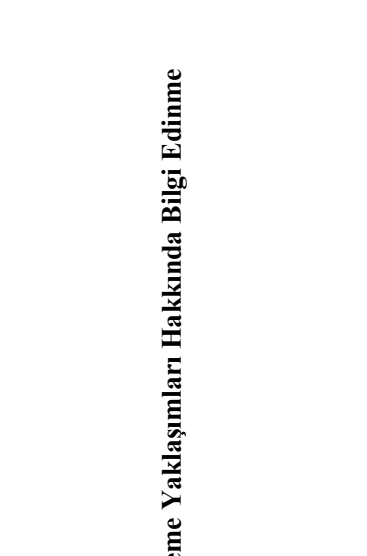 & & 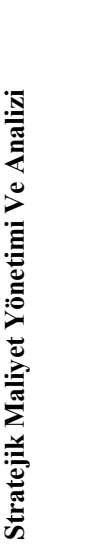 & & 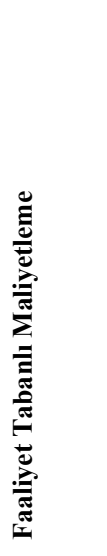 & & & & 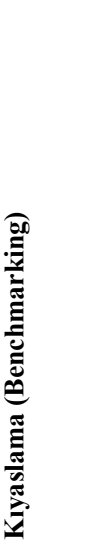 & & 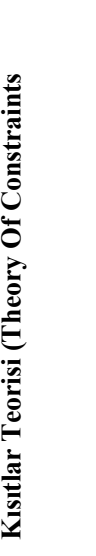 & & 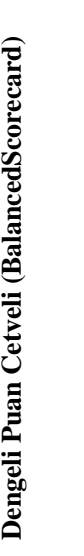 \\
\hline 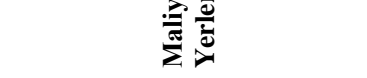 & $\mathbf{n}$ & $\%$ & $\mathbf{n}$ & $\%$ & $\mathbf{n}$ & $\%$ & $\mathbf{n}$ & $\%$ & $\mathbf{n}$ & $\%$ & $\mathbf{n}$ & $\%$ \\
\hline $\begin{array}{l}\text { Aldığım kurs, hizmet içi } \\
\text { eğitim, seminer vs. }\end{array}$ & 6 & 22,2 & 5 & 23,8 & 7 & 25,0 & 9 & 30,0 & 8 & 25,0 & 9 & 24,3 \\
\hline $\begin{array}{l}\text { Almış olduğum üniversite } \\
\text { eğitimi vs. }\end{array}$ & 9 & 33,3 & 6 & 28,6 & 8 & 28,6 & 1 & 33,3 & 7 & 21,9 & 8 & 21,6 \\
\hline Meslektaşlarımdan & 1 & 3,7 & 1 & 4,8 & 1 & 3,6 & 4 & 13,3 & 4 & 12,5 & 5 & 13,5 \\
\hline $\begin{array}{l}\text { Yazıl, görsel dokümanlardan } \\
\text { veya internet }\end{array}$ & 9 & 33,3 & 4 & 19,0 & 1 & 35,7 & 3 & 10,0 & 9 & 28,1 & 6 & 16,2 \\
\hline $\begin{array}{l}\text { Hastanedeki uygulamalar } \\
\text { sırasında }\end{array}$ & 1 & 3,7 & 5 & 23,8 & 2 & 7,1 & 3 & 10,0 & 4 & 12,5 & 8 & 21,6 \\
\hline Diğer & 1 & 3,7 & & 0,0 & & 0,0 & 1 & 3,3 & & 0,0 & 1 & 2,7 \\
\hline Toplam & 27 & 10 & 21 & 100 & 28 & 100 & 30 & 100 & 32 & 100 & 37 & 100 \\
\hline
\end{tabular}

Çalışmada kullanılan soru seti içinde her bir maliyetleme yaklaşımı için altı seçenekli ve katılımcıların birden fazla seçenek işaretleye bilecekleri “....maliyet yaklaşımı hakkında nereden bilgi edindiniz?” sorusu sorulmuştur. Bu soruya verilen cevapların oransal dağılımı Tablo 2'de verilmiştir. Tablo 2'e bakıldığında, katılımcının aldığı kurs, hizmet içi eğitim seminer gibi kaynaklardan öğrenilen en yaygın yaklaşım \%37,5 oranla "Kaizen Maliyetleme", üniversite eğitimi sırasında \%33,3'lük oranla "Stratejik Maliyet Yönetimi Ve Analizi" ve "Kiyaslama (Benchmarking)", meslektaşlar tarafindan \%18,5 ile "Hedef Maliyetleme", yazılı, görsel dokümanlardan veya internet kaynağından \%35,7 oranla "Tam Zamanında Üretim Ortamında Maliyet Yönetimi" ve hastanedeki uygulamalar sırasında \%23,8 oranla "Faaliyet Tabanlı Maliyetleme" yaklaşımıdır. Katılımcıların maliyetleme yaklaşımları konusunda bilgi edinme yoları ilk üç sırayı sırasıyla; hizmet içi eğitim seminerler, üniversite eğitimi sırasında ve yazılı, görsel dokümanlardan veya internet kaynağı oluşturmaktadır. 
Tablo 3. İleri Maliyet Yaklaşımlarının Katılımcılar Tarafından Haberdar Olma Durumları

\begin{tabular}{lccc}
\hline Maliyet Yaklaşımı & Cevaplar & N=14 & \% \\
\hline Değer Yaratmayan Maliyetlerin Ortadan Kaldırılması & Evet & 14 & 100 \\
\hline Ürün Yaşam Seyrince Maliyetleme & Evet & 13 & 92,9 \\
\cline { 2 - 4 } Hedef Maliyetleme & Hayır & 1 & 7,1 \\
\hline KaizenMaliyetleme & Evet & 14 & 100 \\
\hline Değer Mühendisliği & Evet & 13 & 92,9 \\
\hline Kalite Maliyetleri & Hayır & 1 & 7,1 \\
\hline Stratejik Maliyet Yönetimi Ve Analizi & Evet & 14 & 100 \\
\hline Faaliyet Tabanlı Maliyetleme & Evet & 14 & 100 \\
\hline Tam Zamanında Üretim & Evet & 14 & 100 \\
\hline Kıyaslama (Benchmarking) & Evet & 12 & 85,7 \\
\hline Kısıtlar Teorisi & Hayır & 2 & 14,3 \\
\hline Dengeli Puan Cetveli (BalancedScorecard) & Evet & 14 & 100 \\
\hline
\end{tabular}

Maliyetleme yaklaşımlarının katılımcılar tarafından haberdar olma durumlarını gösteren Tablo 3 incelendiğinde, katılımcıların tamamına yakını yüksek oranlarda maliyetleme yaklaşımlarını daha önceden duydukları anlaşılmaktadır. Katılımcıların, Maliyetleme yaklaşımlarından "Faaliyet Tabanlı Maliyetleme" yaklaşımını diğer yaklaşımlara nazaran çok az bir oranla daha az haberdar oldukları anlaşılmaktadır.

Tablo 4. İleri Maliyet Yaklaşımlarının Katılımcılar Tarafından Bilinip Bilinmeme Durumları

\begin{tabular}{lccc}
\hline Maliyet Yaklaşımı & Cevaplar & $\mathbf{N}=\mathbf{1 4}$ & $\mathbf{\%}$ \\
\hline Değer Yaratmayan Maliyetlerin Ortadan Kaldııılması & Evet & 14 & 100 \\
\hline Ürün Yaşam Seyrince Maliyetleme & Evet & 12 & 85,7 \\
\hline Hedef Maliyetleme & Hayır & 1 & 7,1 \\
\hline KaizenMaliyetleme & Evet & 14 & 100 \\
\hline Değer Mühendisliği & Evet & 12 & 85,7 \\
\hline Kalite Maliyetleri & Hayır & 1 & 7,1 \\
\hline Stratejik Maliyet Yönetimi Ve Analizi & Evet & 14 & 100 \\
\hline Faaliyet Tabanlı Maliyetleme & Evet & 14 & 100 \\
\hline Tam Zamanında Üretim & Evet & 14 & 100 \\
\hline Kiyaslama (Benchmarking) & Evet & 10 & 71,4 \\
\hline Kısıtlar Teorisi & Hayır & 2 & 14,3 \\
\hline Dengeli Puan Cetveli (BalancedScorecard) & Evet & 14 & 100 \\
\hline
\end{tabular}

Tablo 4 incelendiğinde yine katılımcıların maliyetleme yaklaşımlarından haberdar olma durmalarındaki gibi yüksek oranda maliyetleme yaklaşımlarını bildikleri anlaşılmaktadır. Yine "Faaliyet Tabanlı Maliyetleme" yaklaşımı diğer yaklaşımlara nazaran daha düşük oranla bilgi sahibi oldukları anlaşılmaktadır. 
Tablo 5. Katılımcılara Göre Hastanede İleri Maliyet Yaklaşımlarının Uygulanabilirlik Durumu

\begin{tabular}{|c|c|c|c|}
\hline Maliyet Yaklaşımı & Cevap & $N=14$ & $\%$ \\
\hline \multirow{4}{*}{ Değer Yaratmayan Maliyetlerin Ortadan Kaldırılması } & Evet & 11 & 78,6 \\
\hline & Kismen & 2 & 14,3 \\
\hline & Hayır & 1 & 7,1 \\
\hline & Toplam & 14 & 100,0 \\
\hline \multirow{4}{*}{ Ürün Yaşam Seyrince Maliyetleme } & Evet & 7 & 50,0 \\
\hline & Kismen & 5 & 35,7 \\
\hline & Hayır & 2 & 14,3 \\
\hline & Toplam & 14 & 100,0 \\
\hline \multirow{4}{*}{ Hedef Maliyetleme } & Evet & 7 & 50,0 \\
\hline & Kismen & 6 & 42,9 \\
\hline & Hayır & 1 & 7,1 \\
\hline & Toplam & 14 & 100,0 \\
\hline \multirow{4}{*}{ KaizenMaliyetleme } & Evet & 8 & 57,1 \\
\hline & Kismen & 2 & 14,3 \\
\hline & Hayır & 2 & 14,3 \\
\hline & Toplam & 12 & 85,7 \\
\hline \multirow{4}{*}{ Değer Mühendisliği } & Evet & 1 & 7,1 \\
\hline & Kismen & 10 & 71,4 \\
\hline & Hayır & 3 & 21,4 \\
\hline & Toplam & 14 & 100,0 \\
\hline \multirow{3}{*}{ Kalite Maliyetleri } & Evet & 13 & 92,9 \\
\hline & Kismen & 1 & 7,1 \\
\hline & Toplam & 14 & 100,0 \\
\hline \multirow{3}{*}{ Stratejik Maliyet Yönetimi ve Analizi } & Evet & 8 & 57,1 \\
\hline & Kismen & 6 & 42,9 \\
\hline & Toplam & 14 & 100,0 \\
\hline \multirow{4}{*}{ Faaliyet Tabanlı Maliyetleme } & Evet & 7 & 50,0 \\
\hline & Kismen & 2 & 14,3 \\
\hline & Hayır & 1 & 7,1 \\
\hline & Toplam & 10 & 71,4 \\
\hline \multirow{4}{*}{ Tam Zamanında Üretim Ortamında Maliyet Yönetimi } & Evet & 7 & 50,0 \\
\hline & Kismen & 4 & 28,6 \\
\hline & Hayır & 3 & 21,4 \\
\hline & Toplam & 14 & 100,0 \\
\hline \multirow{4}{*}{ Kiyaslama (Benchmarking) } & Evet & 10 & 71,4 \\
\hline & Kismen & 3 & 21,4 \\
\hline & Hayır & 1 & 7,1 \\
\hline & Toplam & 14 & 100,0 \\
\hline \multirow{3}{*}{ Kisttlar Teorisi (Theory Of Constraints) } & Evet & 12 & 85,7 \\
\hline & Kismen & 2 & 14,3 \\
\hline & Toplam & 14 & 100,0 \\
\hline \multirow{3}{*}{ Dengeli Puan Cetveli (BalancedScorecard) } & Evet & 10 & 71,4 \\
\hline & Kismen & 4 & 28,6 \\
\hline & Toplam & 14 & 100,0 \\
\hline
\end{tabular}

İleri maliyet yaklaşımlarının uygulanabilirliği ile ilgili olarak katılımcıların düşüncelerini gösteren Tablo 5'e göre katılımcılar hastanelerinde en fazla "Kalite Maliyetleri” yaklaşımını uygulanabilir bulmakta ve bunu sirasıly Kalite Maliyetleri (\%92,9), Kısıtlar Teorisi $(\% 85,7)$ ve Değer Yaratmayan Maliyetlerin Ortadan Kaldırılması $(\% 78,6)$ takip etmektedir. 
Tablo 6. Katılımcıların Hastanelerde Kârlılığı Ve Maliyetleri Etkileyen Faktörler Hakkındaki Görüşleri

Hastanelerde Kârlılı̆̆ı ve Maliyetleri Etkileyen Faktörler

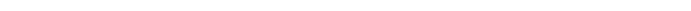

\begin{tabular}{|c|c|c|c|}
\hline Fiyatlarının tek taraflı belirlenmesi karlılığı azaltır & 14 & 2,57 &, 755 \\
\hline $\begin{array}{l}\text { Hastanelerin kendine özgü maliyetlerini sağlık uygulama tebliğinin dikkate almadan belirlemesi } \\
\text { karlılığı azaltır }\end{array}$ & 14 & 2,71 &, 611 \\
\hline Piyasa fiyatları dikkat alınmadan tıbbi malzeme maliyetlerinin belirlenmesi karlılığı azaltır & 14 & 2,28 & ,825 \\
\hline $\begin{array}{l}\text { İçeriğine Bakılmaksızın Ayaktan Hastalarda Vaka Başı Ödeme Yöntemi Uygulanması Karlılığı } \\
\text { azaltır }\end{array}$ & 14 & 2,78 &, 578 \\
\hline $\begin{array}{l}\text { Tam Gün Yasasının uygulanması sonucunda hekimlerin kişisel hizmet üretim yapamamaları karlılı̆̆ } 1 \\
\text { azaltır }\end{array}$ & 14 & 2,07 &, 730 \\
\hline SGK'nın maliyetlere yönelik politikaları karlılığı azaltır & 14 & 2,71 &, 825 \\
\hline Sağlık kurumlarına özel veya genel bütçeden ödenek kıstlılığı yapılması karlılığı azaltır & 14 & 3,14 &, 534 \\
\hline Sağlık kurumlarında bütçe disiplinin olmayışı karlılığı azaltır & 14 & 2,78 & ,801 \\
\hline $\begin{array}{l}\text { Sağlık kurumlarında stratejik karar alma ve planlamaya yönelik maliyet hesaplama sisteminin } \\
\text { olmaması karlılığı azaltır }\end{array}$ & 14 & 2,71 &, 825 \\
\hline Kamu ihale kanununa tıbbi cihaz alımlarındaki sınırlamaları maliyetleri artırmaktadır & 14 & 2,35 & ,633 \\
\hline $\begin{array}{l}\text { Sağlık kurumlarında çalışan personelin } 657 \text { devlet memurları kanununa göre çalıştırılması } \\
\text { maliyetleri artırmaktadır }\end{array}$ & 14 & 2,14 & ,770 \\
\hline
\end{tabular}

Kaynak planlamasının sağlık kurumları yönetimi tarafından yapılmaması maliyetleri artırır

Hastane yönetimlerinin ilaç ve tıbbi malzeme alımlarında inisiyatif kullanamamaları ödeme süresine bağlı olarak maliyet artışına neden olur

\begin{tabular}{|c|c|c|c|}
\hline Hastanelerde ilaç ve malzeme stoku yönetiminin doğru yönetilmemesi maliyetleri artırır & 14 & 4,35 & ,744 \\
\hline $\begin{array}{l}\text { Sağlık kurumlarında etkin bir maliyet ve performans sisteminin olmaması maliyetlerin doğru } \\
\text { yönetilememesine neden olur }\end{array}$ & 14 & 4,00 & ,679 \\
\hline Hastanelerde tıbbi donanım fazlalığı maliyetleri artırır & 14 & 3,92 & ,997 \\
\hline Hizmet kalite standartlarını yönelik yapılan çalışmalar maliyetleri artırır & 14 & 3,21 & ,801 \\
\hline $\begin{array}{l}\text { SGK'nın hizmet birim maliyetlerine yönelik kısıtlamaları kalitesizlik maliyetine neden } \\
\text { olmaktadır }\end{array}$ & 14 & 3,42 &, 513 \\
\hline $\begin{array}{l}\text { SGK'nın hasta faturalarına yönelik kesinti yapması hizmet kalitesine bağlı olarak maliyetlerini } \\
\text { artırır }\end{array}$ & 14 & 2,92 & ,730 \\
\hline $\begin{array}{l}\text { sağlık kuruluşlarında farklı katkı paylarının alınması sağlık hizmeti üretim maliyetlerini } \\
\text { artırmaktadır, }\end{array}$ & 14 & 2,57 & ,755 \\
\hline Bilimsel araştırma projelerine kaynak aktarılması hizmet üretim maliyetlerini artırır & 14 & 4,35 & ,744 \\
\hline Hazineye kaynak aktarımı hizmet üretim maliyetlerini artırmaktadır & 14 & 4,42 & ,646 \\
\hline Gereksiz hizmet kullanımını artması hizmet üretim maliyetlerini artırmasına sebep olur & 14 & 2,21 & ,892 \\
\hline $\begin{array}{l}\text { Mevcut uygulanan sağlık hizmetleri fiyat listesi sağlık kurumlarının sağlık hizmeti üretim } \\
\text { maliyetlerini karşılamaktadır }\end{array}$ & 14 & 2,35 & ,744 \\
\hline $\begin{array}{l}\text { Sağlık kurumlarında uygulanan çekirdek kaynak yönetim sistemi hizmet maliyetini } \\
\text { düşürmektedir }\end{array}$ & 14 & 3,57 & ,089 \\
\hline $\begin{array}{l}\text { Finansal yönetim bilgi sistemi doğrultusunda sağlık kurumlarında stratejik karar alma ve } \\
\text { planlama yapılmaktadır }\end{array}$ & 14 & 2,05 & ,646 \\
\hline Sağlık kurumlarında dışarıdan hizmet satın alınması maliyetleri azaltır & 14 & 4,21 & 699 \\
\hline $\begin{array}{l}\text { Tıbbi malzeme tedarikçilerinin tekel oluşturmaları malzeme maliyetlerinin yüksek olmasına } \\
\text { neden olur }\end{array}$ & 14 & 3,42 & ,851 \\
\hline
\end{tabular}

Katılımcıların hastanelerde kârlılığı ve maliyetleri etkileyen faktörler hakkındaki görüşleri Tablo 6 incelendiğinde, en yüksek ve en düşük ortalama değerleri alan ilk 5 faktör aşağıda sıralanmıştır.

En yüksek ortalama değer alan ilk beş faktör; 
Döner sermayeden hazineye kaynak aktarımı üretim maliyetlerini artırmaktadır(ort=4,42, \pm 646 )

Döner sermayeden bilimsel araştırma projelerine kaynak aktarımı hizmet üretim maliyetlerini artırır (ort $=4,35 \pm, 744)$

Hastane yönetimlerinin ilaç ve tıbbi malzeme alımlarında inisiyatif kullanamamaları ödeme süresine bağlı olarak maliyet artışına neden olur (ort $=4,21 \pm, 578)$

Sağlık kurumlarında dışarıdan hizmet satın alınması maliyetleri azaltır (ort=4,21, \pm 699$)$

Sağlık kurumlarında etkin bir maliyet ve performans sisteminin olmaması maliyetlerin doğru yönetilememesine neden olur (ort $=4,00 \pm, 679$ )

En düşük ortalama değer alan ilk beş faktör;

Finansal yönetim bilgi sistemi doğrultusunda sağlık kurumlarında stratejik karar alma ve planlama yapilmaktadır(ort $=2,05 \pm, 646$ )

Tam Gün Yasasının uygulanması sonucunda hekimlerin kişisel hizmet üretim yapamamaları karlılığı azaltır (ort $=2,07 \pm, 730)$

Sağlık kurumlarında çalışan personelin 657 devlet memurları kanununa göre çalıştırılması maliyetleri artırmaktadir (ort $=2,14 \pm, 770)$

Performansa dayalı ek ödeme sistemine bağlı olarak gereksiz hizmet kullanımını artması hizmet üretim maliyetlerini artırmasına sebep olur (ort $=2,21 \pm, 892$ )

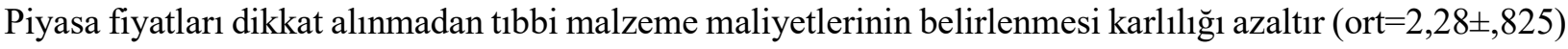

Kamu ihale kanununa tıbbi cihaz alımlarındaki sınırlamaları maliyetleri artırmaktadır (ort $=2,35 \pm, 633)$

Mevcut uygulanan sağlık hizmetleri fiyat listesi sağlık kurumlarının sağlık hizmeti üretim maliyetlerini

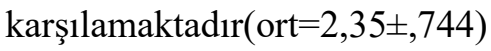

\section{TARTIȘMA}

Hastanelerde sunulan hizmetlerin etkili, etkin ve sürdürülebilir bir şekilde verilebilmesinin yanında eldeki kaynakların gereken şekilde etkin ve verimli kullanılabilmesi özellikle mali kaynakların yönetilmesini organize eden ve planlayanlar açısından önem arz etmektedir. Bu bağlamda sözü edilen çalışanların maliyet yönetimi hakkında bilgi, beceri ve tecrübeye sahip olmalarını gerektirmektedir. Bu sebeple bu çalışma, hastane yöneticilerinin maliyet yönetimi hakkında bilgi ve becerileri açısından ne durumda olduklarını tespit edilerek hastanelerde yönetici görevinde bulunan çalışanların istihdamında maliyet yönetimi açısından değerlendirilmelerinin gerekliliği açısından önemli olarak değerlendirilmektedir.

Maliyetleme yaklaşım modellerinin önceden duyulup duyulmadığı, bu yaklaşımlar hakkında bilgiye sahip olunup olunmadığı ve ilgili yaklaşımların katılımcıların aktif olarak görev aldıkları kurumlarında uygulanabilirliği hakkındaki düşünceleri değerlendirildiğinde katılımcıların maliyetleme yaklaşım modellerini daha önce duydukları ve hakkında bilgiye sahip oldukları anlaşılmıştır. Çarıkçı (2014) tarafından yapılan çalışmada da benzer bir sonuç elde edilmiş ve ağırlıklı olarak tüm yaklaşımların daha önce duyulduğu ve bilgiye sahip olunduğu belirtilmiştir.

Bu çalışmada katılımcıların, söz konusu maliyet yaklaşımlarının hastanelerinde uygulanabilirliği ile ilgili olarak kararsız kaldıkları görülmektedir. Tablolardaki bilgiler göre söz konusu yaklaşımların uygulanabilirliğine yönelik alınan cevapların yüzde dağılımı 50-57 arasında değişmektedir. Bu kapsamda katılımcılar ileri maliyet yaklaşımlarını daha önce duyduklarını ve bilgiye sahip olduklarını ifade etmiş̧lerdir. Ancak yaklaşımların uygulanmamasının sebebi hastanelerin yatak kapasiteleri ve performanslarından kaynaklanabilir. 
Katılımcıların Maliyetleme Yaklaşımları Hakkında Bilgi Edinme Yerlerine Göre Dağılımı konusunda katılımcının aldığı kurs, hizmet içi eğitim seminer gibi kaynaklardan öğrenilen en yaygın yaklaşım "Kaizen Maliyetleme", üniversite eğitimi sırasında "Stratejik Maliyet Yönetimi Ve Analizi" ve "Kiyaslama (Benchmarking)", meslektaşlar tarafından "Hedef Maliyetleme", yazıl1, görsel dokümanlardan veya internet kaynağından "Tam Zamanında Üretim Ortamında Maliyet Yönetimi” ve hastanedeki uygulamalar sırasında "Faaliyet Tabanlı Maliyetleme" yaklaşımı olarak belirlenmiştir. Ayrıca katılımcıların maliyetleme yaklaşımları konusunda bilgi edinme yoları ilk üç sırayı sırasıyla; hizmet içi eğitim seminerler, üniversite eğitimi sırasında veyazılı, görsel dokümanlardan veya internet kaynağı oluşturmaktadır.

Çarıkçı (2014) tarafindan yapılan çalışmada da benzer sonuçlar çıkmasına karşın bu çalışmadan farklı olarak sadece "Hedef Maliyetleme Yaklaşımı" en düşük yaklaşım olduğu gözlemlenmiştir.

Bekçi ve Özal tarafından 2010 yılında, stratejik maliyet yönetiminin sağlık işletmelerine uygulanabilirliğine yönelik yapılan araştırma birebir bu çalışma ile örtüşmese de söz konusu çalı̧̧mada katılımcılar ileri maliyet yönetimi yaklaşımlarından tam zamanında üretim ve kalite maliyetlemenin daha uygulanabilir olduğunu ifade etmişlerdir (Bekçi ve Özal, 2010).

Koçyiğit vd. (2019) tarafından yapılan ve en güncel çalışma olan bu çalışmada özel sektör kuruluşlarında söz konusu ileri maliyet yaklaşımlarının daha fazla uygulabilir olduğu görülmektedir. Ayrıca bu çalışmada katılımcılar hastanelerde stratejik maliyet yönetimi araçlarından; "mamul/hizmet yaşam dönemi maliyetleme yöntemi" dışındaki bütün stratejik maliyet yönetimi araçlarının uygulanabilir olduğunu ifade etmişlerdir (Koçyiğit vd. 2019).

Araştırma soruları ile tanımlayıcı istatiksel veriler karşılaştırıldığında katılımcıların çalışmaya konu edilen yaklaşımlar hakkında haberdar olma düzeylerinin yüksek olduğu ve bu sonuca bağlı olarak da sözkonusu yaklaşımlarının büyük çoğunluğu hakkında bilgi sahibi oldukları görülmektedir. Ayrıca katılımcıların büyük çoğunluğu ileri maliyet yönetimi yaklaşımlarının hastanelerinde uygulanabileceğini ve bu yaklaşımların aynı zamanda karlılığı ve maliyetleri etkilen bir faktör olduğunu düşünmektedir.

\section{SONUÇ}

Sağlık sektörü önceki bölümlerde ifade edildiği üzere nevi şahsına münhasır özelliklerinden dolayı diğer sektörlerden ayrılmaktadır. Literatür çalışmalarında da ortaya konulduğu üzere böylesi bir sektörün finansmanı elbet güç olmaktadır. Politika belirleyicilerinin özellikle kamu sağlık hizmetlerinin finansmanı ile ilgili etkin politikalar geliştirerek, bu alanda maliyeti düşürürken hizmetin kalitesini ve etkinliğini azaltacak düzenlemelerden kaçınmaktadırlar. Bu durumda sağlık hizmetlerinde maliyet yönetimi ile ilgili etkin düzenlemeleri içeren politikaların üretilmesi önem arz etmektir.

Hastaneler sağlık hizmetleri sektöründe iş yükü anlamında sağlık hizmetini büyük kısmını karşılayan, emek yoğun ve en karmaşık işletmelerin başında gelmektedir. Bu karmaşık organizasyonun gerek organizasyonel anlamda yönetimi gerekse mali açıdan yönetilmesi karmaşık ve güç olmaktadır. Sağlık hizmetlerinin odağında insanın olması verilen hizmetin önemini bir kez daha gösterir niteliktedir. Bu denli önemli hizmetin devamlılığı için etkili ve etkin bir maliyet yönetiminin sağlanması özel önem arz etmektedir. Hizmetin sürekliliği ve kalitesinde düşüşe sebep olmadan hastanede mali yönetimle ilgili olana yöneticilerin maliyetleme yaklaşımlarının hangisini uygulayacakları üzerinde durulması gereken bir konu olarak değerlendirilmelidir.

Çalışma sonuçları öncelikle katılımcıların tamamına yakınının maliyet yönetimi yaklaşımlarını daha önceden duyduklarını göstermektedir. Katılımcıların, maliyet yönetimi yaklaşımlarının tamamına yakınından haberdar olma seviyelerinin yüksek olması, Artvin kamu hastanelerinde bu yaklaşımları uygulanması sürecinde yaşanacak olan sorunların çözülmesine yardımcı olacaktır. 
Çalışmadan çıkarılacak bir diğer sonuç ise; yine katılımcıların maliyetleme yaklaşımlarından haberdar olma durmalarındaki gibi yüksek oranda maliyetleme yaklaşımlarını bildikleri anlaşılmaktadır. Ancak yaklaşımlardan "Faaliyet Tabanlı Maliyetleme" yaklaşımı, katılımcıların diğer yaklaşımlara nazaran da az bilgiye sahip olduğu görülmüştür. Günümüzde sektörde ayakta kalmak ve devamlılığ sağlamak işletmeler açısından hayati öneme sahiptir. Bu bağlamda yöneticilerin ileri maliyetleme yaklaşımları konusunda bilgi sahibi olmaları onların kaliteli, sürekli iyileşme ve gelişme, verimlilik ve etkinliği üst düzeyde tutma ve proaktif yaklaşımla stratejik kararlar verebilme gibi işletmeyi özel ve değerli kılacak uygulamaları yapmasını sağlayacaktır. Dolayısıyla katılımcılar ileri maliyet yönetimi yaklaşımlarının hastanelerinde uygulanabileceğini düşünmektedirler.

Çalışmada katılımcılar özellikle döner sermayeden hazineye ve bilimsel araştırma fonuna kaynak aktarımının yapılmasının, malzeme alımlarında hastane yönetimlerinin insiyatif kullanamamalarının sonucunda vadelerin uzamas1, hizmet alımı yapılması ve etkin bir maliyet performans sistemin kurulmamasının Artvin kamu hastanelerinin karlılığını ve maliyetleri olumsuz yönde etkilediği görüşündedirler. Bu bağlamda çalışma sonuçlarında da öne çıkan yaklaşımlar olan "Kalite Maliyetleri", "Kısıtlar Teorisi" ve "Değer Yaratmayan Maliyetlerin Ortadan Kaldırılması" gibi ileri maliyet yaklaşımı yöntemleri kullanılarak söz konusu olumsuzlukları giderme noktasında çözüm üretilebilir. Bu nedenle günümüzde ileri maliyet yaklaşımlarının yöneticiler tarafından kaçınılmaz olarak benimsenerek değerlendirilmesi ve Artvin kamu hastanelerinde uygulanması önem arz etmektedir.

Bundan sonra yapılacak çalışmalarda farklı sektörleri kıyaslamak amacıyla ileri maliyet yönetimi yaklaşımlarındaki algılarının belirlenmesi noktasında kamu ve özel hastanede çalışan yöneticileri kapsayan araştırmalar yapılabilir. Çalışmanın daha farklı bakış açılarıyla ele alınarak araştırılması da araştırmacıları farklı sonuçlara götürebilecektir.

\section{KAYNAKLAR}

Akdoğan, N. (1998). Maliyet Muhasebesi Uygulamaları. Gazi Kitabevi.

Altay, A. (2007). Sağlık Hizmetlerinin Sunumunda Yeni Açılımlar ve Türkiye Açısından Değerlendirilmesi, Saylştay Dergisi, 64, 33-58

Ardıç, M. (2010). Maliyet Yönetimi Yaklaşımları ve Devlet Orman İşletmelerinde Uygulanabilirliklerinin Araştırılması (Yayımlanmamış Doktora Tezi). Atatürk Üniversitesi Sosyal Bilimler Enstitüsü İşletme Ana Bilim Dalı.

Bekçi, İ. \& Özal, H. (2014). Stratejik Maliyet Yönetiminin Sağlık Sektöründe Uygulanabilirliğine Yönelik Bir Araştırma. Akademik Araştırmalar ve Çalışmalar Dergisi (AKAD), 2(3), 78-97.

Büyükmirza, K. (2012). Maliyet ve Yönetim Muhasebesi, Tekdüzen'e Uygun Bir Sistem Yaklaşımı, 17. Baskı. Gazi Kitabevi

Çarıkçı, O. (2014). İleri Maliyet Yönetimi Yaklaşımlarının Hastane Yöneticileri Tarafından Algılanma Düzeyleri Üzerine Bir Araştırma (Yayımlanmamış Doktora Tezi). Süleyman Demirel Üniversitesi Sosyal Bilimler Enstitüsü İşletme Anabilim Dalı.

Gürsoy, C. T. (1997). Yönetim ve Maliyet Muhasebesi. Lebib Yalkın Yayımları.

İncesu, E. (2013). Hastane İşletmelerinde Kalite Maliyet Analizi: Konya Seydişehir Devlet Hastanesi'nde Bir Uygulama, Sağllkta Performans ve Kalite Dergisi, 6, 113-141

Karcıŏlu, R., (2000). Stratejik Maliyet Yönetimi: Maliyet ve Yönetim Muhasebesinde Yeni Yaklaşımlar, Aktif Yayınevi.

Koçyiğit:Ç., Doğan, E. \& Sula, H. (2019). Hastane İşletmelerinde Stratejik Maliyet Yönetiminin Uygulanabilirliğini Tespit Etmeye Yönelik Bir Araştırma: Ankara İli Özel Hastaneler Örneği. Muhasebe ve Denetime Bakış Dergisi, 18(56), 63-86.

Örnek, A. Ş. (2003). Bir Yönetim Tekniği Olarak Değer Mühendisliği. Dokuz Eylül Üniversitesi Sosyal Bilimler Enstitüsü Dergisi, 5(2), 213-230. 
Özer, Ö. (2015). Türkiye Sağlık Sisteminde Finansal Sürdürülebilirlik: Paydaş Görüşleri ve Değerlendirmeleri (yayımlanmamış Doktora Tezi). Hacettepe Üniversitesi, Sosyal Bilimler Enstitüsü Sağlık Kurumları Yönetimi Ana Bilim Dalı.

Özgen, H. \& Tatar, M. (2007). Sağlık Sektöründe Bir Verimlilik Değerlendirme Tekniği Olarak Maliyet-Etkinlik Analizi ve Türkiye'de Durum, Hacettepe Sağlık Idaresi Dergisi, 10(2),109-137

Özgener, Ş. \& Küçük, F. (2008). Hastanelerde Modern Yönetim Felsefesinin Verimliliğe Etkisi: Gevher Nesibe Hastanesinde Bir Uygulama. Selçuk Üniversitesi Sosyal Bilimler E. Dergisi, 20, 341-358

Özgülbaş, N. \& Tarcan, M. (2013). Sağlık Kurumlarında Maliyet Yönetimi, AÖF Yayınları, Eskişehir

Özkan, M., Turgut, N., Ay, A. \& Uslu, K. (2013). Hastanelerde Modern Yönetim Felsefesinin Verimliliğe Etkisi: Eğitim ve Araştırma Hastanesi Uygulaması. Okmeydanı Tıp Dergisi, 29(1), 26-32.

Robertson J, Lang DL, Hill S (2003). Use of pharmacoeconomics in prescribing research. Part 1: Costs - Moving beyond the acquisition price for drugs. J Clin Pharmacy and Therapeutics, 28, 73- 79.

Saraçoğlu: \& Öztürk, F. (2017). Sağlık Hizmetlerine Yönelik Talebin Belirleyicileri: Türkiye Üzerine Bir Uygulama. İşv ve Hayat, 2(4), 293-342.

Tatarlı, N. (2007). Sağlık Hizmetlerinde Hasta Tatminini Etkileyen Unsurlar ve Sağlık Sektöründe Bir Uygulama, Abant İzzet Baysal Üniversitesi Sosyal Bilimler Enstitüsü, Yayınlanmış Yüksek Lisans Tezi

Yüzbaşığlu, N. (2004). İşletmelerde Stratejik Yönetim ve Planlama Açısından Stratejik Maliyet Yönetimi Enstrümanları. Selçuk Üniversitesi Sosyal Bilimler Enstitüsü Dergisi, 12, 387-410 